\title{
On Two New Specimens of Spencerites insignis.
}

\author{
BY
}

MISS E. M. BERRIDGE, F.L.S.

With Plates XI and XII and three Figures in the Text.

A SPECIMEN of this fossil strobilus from the Coal-Measures of YorkA shire and Lancashire was first described by Professor Williamson as a Lepidostrobus ${ }^{1}$, no specific name being given; later accounts were published of this and other specimens under the names of Lepidostrobus insignis and Lepidodendron Spenceri ${ }^{2}$.

In 1897 this type of cone was the subject of a paper by Dr. Scott ${ }^{3}$, who showed that the distinctive characteristics of the fossil justified its removal, already suggested by Professor Williamson, from the genus Lepidostrobus; Dr. Scott therefore gave a full description of this and an allied species under the names Spencerites insignis and Spencerites majusculus. Until the latter part of 1903 only four examples of the strobilus Spencerites insignis were known. In the summer of that year, however, I found two specimens at Dulesgate, from which some series of sections were cut by Mr. Lomax, among them being the fine radial section which is represented in Pl. XI, Phot. I. The new examples are chiefly remarkable for the good preservation of the sporophylls; these prove to be more complicated than was previously supposed. They also vary considerably in other respects from the specimens described by Dr. Scott; the following account deals chiefly with these points of difference:-

Axis. The diameter of the axis is $5 \mathrm{~mm}$., which is the maximum measurement given by Dr. Scott for the cones. It is evident from this and other measurements that the new specimens are rather large examples of the fossil.

Within the ring of primary wood there is a well-marked pith, the prosenchymatous cells of which are mostly thin-walled, but a strand of thick-walled cells appears near the centre (Phot. $5, \mathrm{~m}$ ).

1 ' Organization of the Fossil Plants of the Coal-Measures,' Part IX, Phil. Trans., I 878.

2 'Organization,' \&c., Parts X, XVI, XIX, Phil. Trans., I880, I889, and I 893.

(i) 'On the Structure and Affinities of Fossil Plants from the Palaeozoic Rocks'; (ii) 'On Spencerites, a new Genus of Lycopodiaceous Cones.' Phil. Trans. Roy. Soc., vol, I89 B, I897.

[Annals of Botany, Vol, XIX. No, LXXIV. April, I905.] 
The protoxylems of the woody cylinder are about twenty in number, this corresponding to the number of orthostichies of sporophylls. The prominence of the angles of the stele formed by the protoxylems varies considerably at different levels in the axis. When the section passes near the level at which a whorl of ten leaf-traces leaves the stele, ten angles are much more clearly marked than the other ten alternate with them; this probably accounts for the fact that ten is given as the number of protoxylems in Dr. Scott's paper.

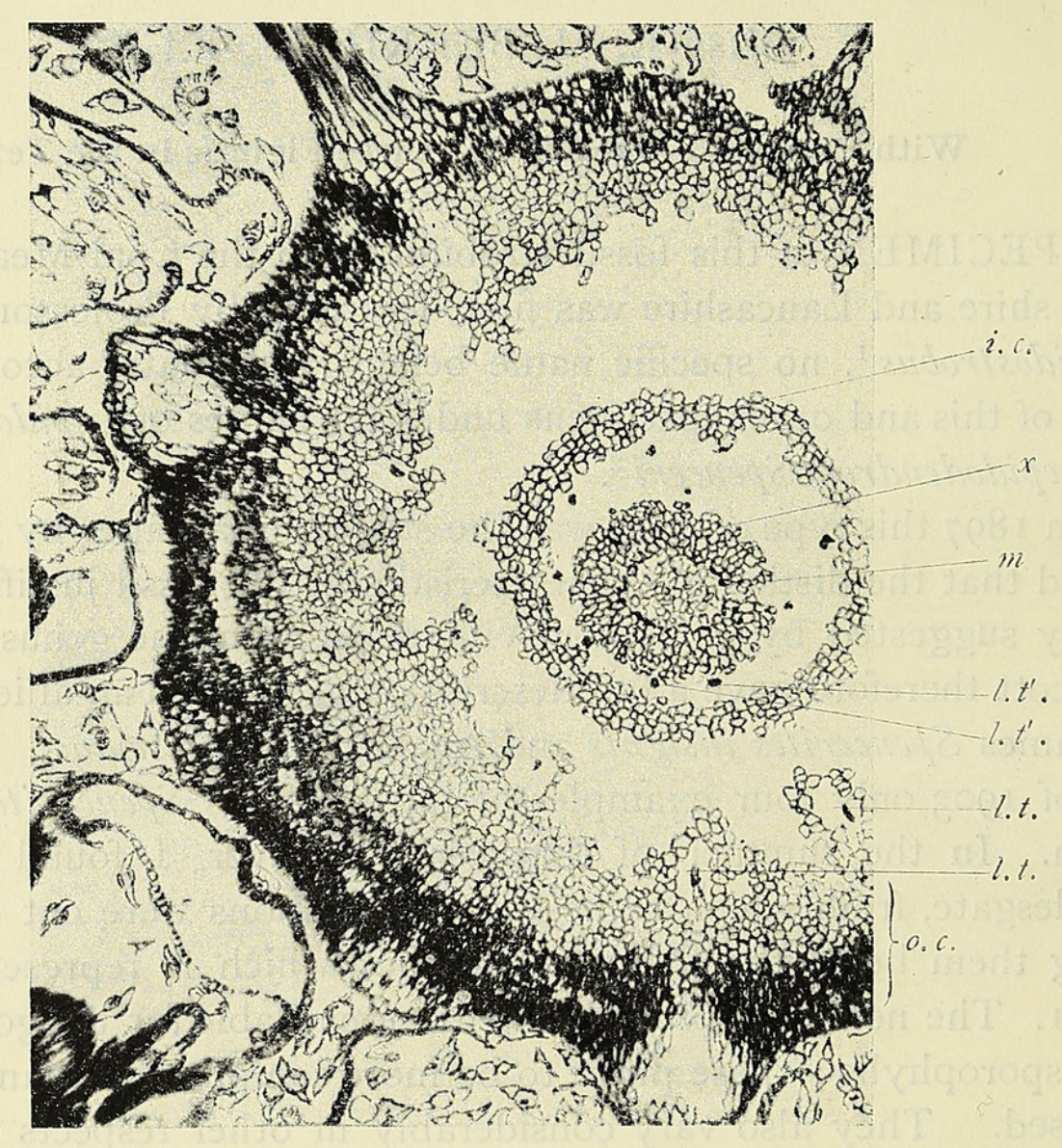

FIG. 2. Transverse section of the axis, showing the two zones of the outer cortex, and two alternating whorls of leaf-traces. $m$, pith; $x$, xylem; i.c., inner cortex; o.c., outer cortex; l.t., l.t., leaf-traces belonging to the onter whorl; $l . t^{\prime} ., l . t^{\prime}$. , leaf-traces belonging to the inner whorl.

Of the zones of tissue surrounding the wood only the inner and outer layers of the cortex remain, the phloem and middle cortex having perished. The inner cortex consists of thickened, somewhat elongated cells, and is in every respect similar to that of previous specimens.

The outer cortex, however, is evidently very variable in this genus. Dr. Scott has taken the specimens showing Dictyoxylon structure as typical, but he mentions other cases in which ' the cell-walls are considerably thickened throughout the external cortex.' In the present examples it appears to be differentiated into two zones; the outer is uniformly thickened, the Dictyoxylon character being absent; the inner consists of 
delicate thin-walled tissue, which, however, shows no trace of the trabecular character of the middle cortex as preserved in certain specimens in the Williamson collection (Phot. IO).

It is evident from the position of the leaf-traces both in the transverse (Fig. 2) and tangential sections (Phot. 2) of the axis, that the sporophylls were arranged in alternating verticils, each whorl consisting of ten sporophylls. Dr. Scott has mentioned this as a probable arrangement in his paper

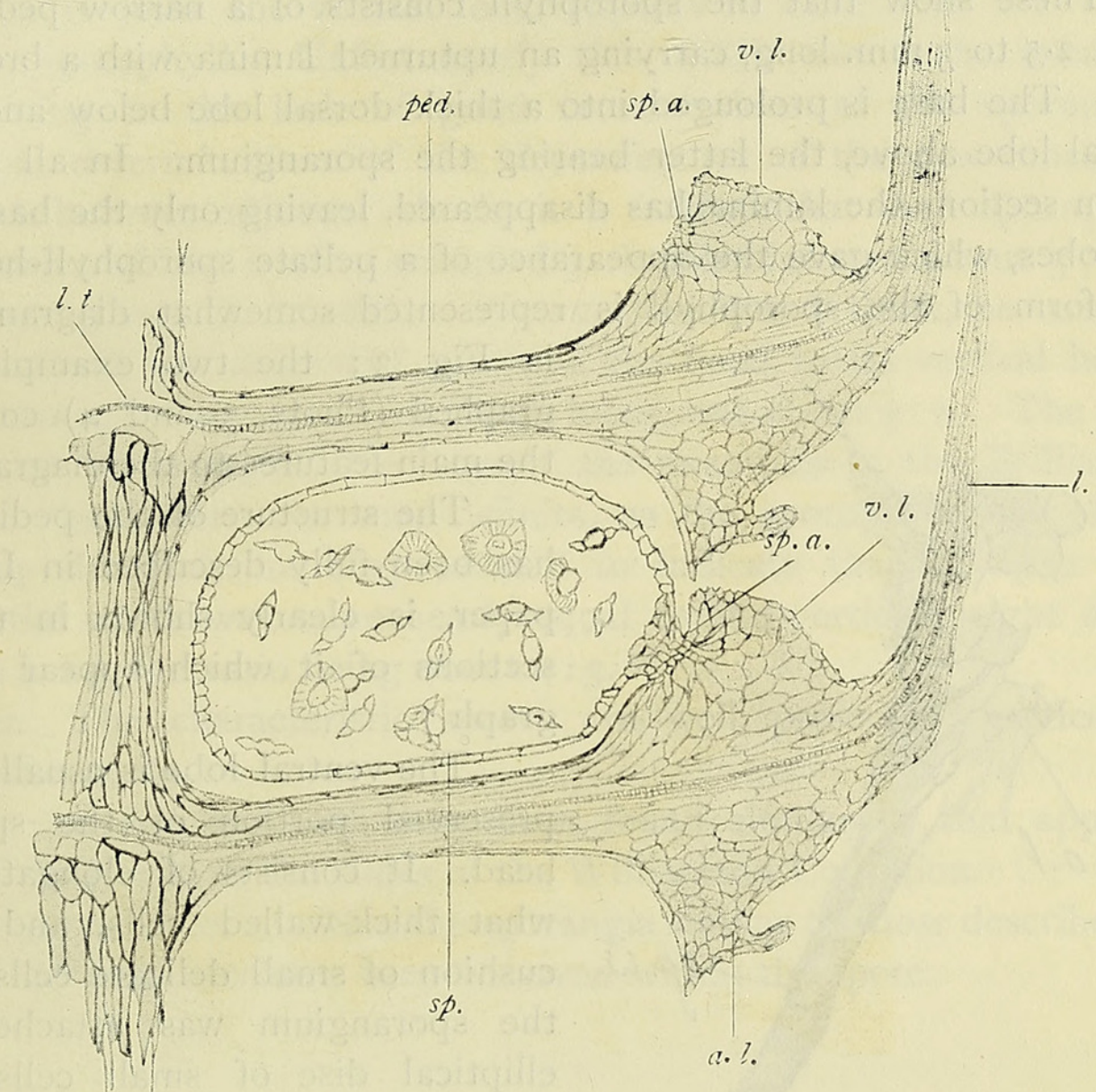

FIG. 3. Diagram showing the probable form of the sporophylls, with one sporangium. $l_{0}$, distal limb; v.l., ventral lobe ; d.l., dorsal lobe ; sp., sporangium; sp.a., sporangial attachment ; ted., pedicel ; l.t., leaf-trace.

'On Spencerites,' and pointed out to me the clear evidence regarding this character furnished by the new slides. He nevertheless considers the phyllotaxy as somewhat variable, being sometimes spiral and sometimes verticillate. Such variability is often present among recent Lycopods; in 'Die natürlichen Pflanzenfamilien' it is mentioned that both a spiral and whorled arrangement of the leaves is frequently to be found at different levels on the same shoot; this is markedly the case in L. Selago.

The whorled arrangement is also evident in Phot. 7, a tangential section of the other specimen, passing through the pedicels of the sporophylls. 


\section{Berridge.-On Two New Specimens of Spencerites insignis.}

The course of the leaf-trace is considerably arched just before it enters the pedicel (Phot. 9). In certain cross-sections, therefore, the same leaf-trace appears twice, as is the case in Phot. 10 (l.t., l.t.), giving the appearance of superposed whorls. The traces of each whorl of sporophylls are inserted on the woody cylinder at the level of the whorl next below.

Sporophylls and Sporangia. Some of the sporophylls of the new cones are exceptionally well preserved, and good radial sections have been obtained of them.

These show that the sporophyll consists of a narrow pedicel, from about 2.5 to $3 \mathrm{~mm}$. long, carrying an upturned lamina with a broad fleshy base. The base is prolonged into a thick dorsal lobe below and a larger ventral lobe above, the latter bearing the sporangium. In all previously known sections the lamina has disappeared, leaving only the base with its two lobes, which gave the appearance of a peltate sporophyll-head. The true form of the sporophyll is represented somewhat diagrammatically

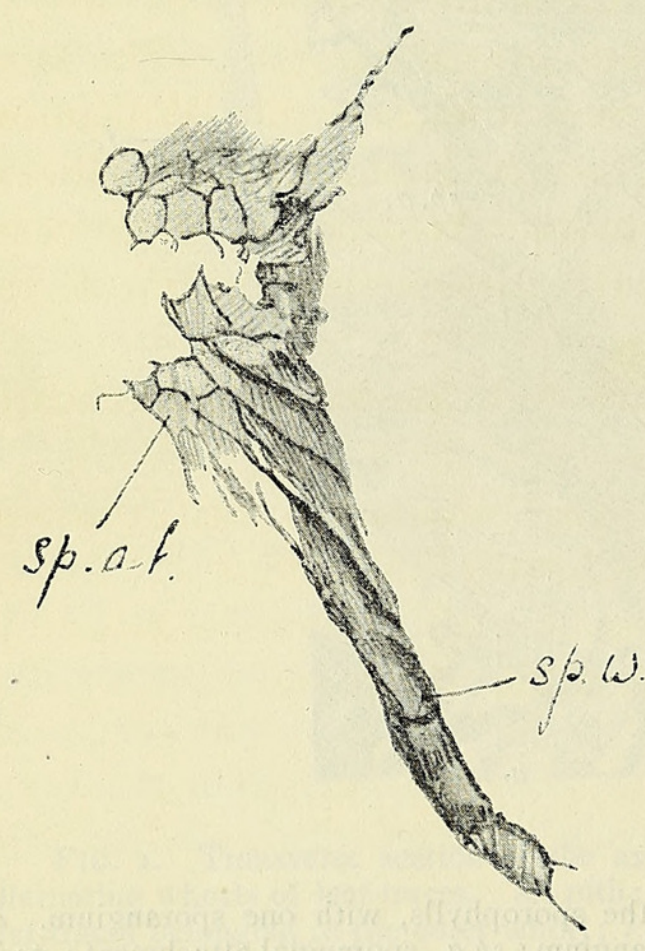

FIG. 4. Portion of sporangium-wall $(s p . w$.$) in continuity with some cells of the$ sporangial attachment $(s p . a t$.$) .$ in Fig. 3 ; the two examples photographed (Phots. 3 and 4) contributing the main features to the diagram.

The structure of the pedicel, which has been fully described in Dr. Scott's paper, is clearly shown in the crosssections of it which appear in photograph 7 .

The ventral lobe is usually the best preserved portion of the sporophyllhead. It consists of elongated, somewhat thick-walled cells, and bears a cushion of small delicate cells to which the sporangium was attached. This elliptical disc of small cells forms a conspicuous object in several of the slides, especially in cases such as that represented in photograph 8 , where it is cut by a section passing more or less parallel to the adaxial surface of the ventral lobe. This section shows that its horizontal width is about $.5 \mathrm{~mm}$. and its vertical breadth about $.3 \mathrm{~mm}$.

In the two cones the sporangium has not been found attached to the lamina, but the sporangium-wall is sometimes continuous with a few small isodiametric cells similar to those of the cushion on the ventral lobe (Fig. 4); the wall appears frequently to have ruptured at the place of attachment.

The distal limb of the sporophyll is best shown in photograph 4 ; in 
this example the dorsal lobe is considerably decayed. The vascular bundle, which is clearly shown in photograph 3 , runs from the pedicel into the lamina, and can, in several cases, be traced passing up it for a considerable distance. It is noteworthy that no branch has been observed passing to the ventral lobe and sporangium.

The surface of the cone was probably completely covered by the leaf-like laminae of the sporophylls, as those of each whorl extended at least to the level of the third whorl above. The broad base of the distal limb, where it joins the ventral lobe, appears to have been the widest part of the sporophyll. Unfortunately this width cannot be measured directly, owing to the lack of good cross-sections of the sporophyllhead. From determinations of the circumference of the new cones, and the distance between adjacent whorls, it is evident that each sporophyllhead, exclusive of the lamina, occupied a rhomboidal area about $3.7 \mathrm{~mm}$. in width by $2.3 \mathrm{~mm}$. in breadth. It may therefore, I think, be assumed that the ratio of the tangential width of the head to its vertical height, measured through the ventral and dorsal lobes, was about $3: 2$. The same measurements were applied to some of the examples in the Williamson Collection; these were not very definite, as the sporophylls are always considerably decayed, but they seemed to indicate that in these cases the tangential width was more nearly equal to the vertical height of the sporophyll head, the ratio being about $4: 3$.

Spores. The characteristic spores are well preserved, particularly in one of the cones.

In no case has any reticulum been found similar to that apparent in some of the spores in the slides of the Williamson Collection.

A few sporules occur within the sporangia similar to those described by Dr. Scott, but only two have been observed within the spore.

\section{SUMMARY.}

The relationship of this family to other genera among the Palaeozoic Lycopods, as outlined by Dr. Scott in his paper, is practically unaffected by the facts brought to light by the examination of the new specimens. The presence of a sporophyll with a leaf-like lamina emphasizes the relationship to the Lepidostrobi and to M. Zeiller's Sigillariostrobus Crepini, but the attachment of the sporangium to the sporophyll-head above its junction with the pedicel is a character which separates it definitely from the former genus. Besides other points of difference, such as the structure of the sporangial wall and of the spores, and also the arrangement of the leaf-traces, Spencerites appears to differ from the Lepidostrobi in having no ligule, no trace of it having been found, although well-preserved 
radial sections through the ventral lobe and sporangial attachment are frequent.

The distal attachment of the sporangium to the sporophyll has suggested a relationship with Sphenophyllum; in that case, the well-marked ventral lobe would represent the sporangiophore of that type. The absence of any trace of a vascular bundle running to the lobe, however, makes this suggestion as to its nature a very doubtful one.

It is evident from the foregoing comparison that the new specimens vary considerably in several points from the examples of Spencerites insignis already known, particularly in the absence of Dictyoxylon structure in the cortex, the more ovoid form of the sporangia (corresponding to a greater length of the sporophyll-pedicel), and the greater tangential width of the sporophyll-head as compared with its vertical height. In these characters the new cones show a closer resemblance to Spcncerites majusculus, and it is questionable whether they do not belong to a species intermediate between $S$. insignis and S. majusculus, though certainly much more closely allied to the former. It seems, however, inadvisable to multiply species, and the differences are hardly greater than such as might possibly occur between a young and old cone, or between the top and bottom portions of a long strobilus.

The diagnosis given by Dr. Scott in his paper 'On Spencerites' must, however, be considerably modified in order to include the new cones as well as those in the Williamson Collection at the Natural History Museum.

With his permission, therefore, I have introduced the following diagnosis, and take this opportunity of gratefully acknowledging the help I have received from him in dealing with this new material.

\section{SPENCERITES.}

Cone, consisting of a cylindrical axis, bearing numerous simple sporophylls, arranged spirally or in crowded alternating verticils. lamina.

Sporophylls, formed of a sub-cylindrical pedicel expanding into a large

Sporangia, solitary on each sporophyll, inserted by a narrow base on the upper surface of the lamina, but free from the pedicel.

Sporangial wall, formed of a single layer of prosenchymatous cells

Spores, winged.

SPENCERITES INSIGNis (Will.).

Cone, pedunculate, peduncle bractigerous.

Whole cone, 8 to $10 \mathrm{~mm}$. in diameter.

Axis, 3.5 to $5 \mathrm{~mm}$. in diameter. 
Sporophylls. Pedicel from 2 to $3 \mathrm{~mm}$. long, expanding into a distal limb bearing ventral and dorsal lobes.

Sporangia, spherical or ovoid, seated on the ventral lobe.

Spores, tetrahedral, becoming spheroidal when free, with a hollow equatorial wing. Maximum diameter of spore without wing, about $0.14 \mathrm{~mm}$.; with wing, about $0.28 \mathrm{~mm}$.

Wood of axis, 20-arch, without prominent angles; with or without pith.

Locality, near Halifax and Huddersfield, and at Dulesgate.

Horizon, Lower Coal-Measures.

\section{EXPLANATION OF PLATES XI AND XII.}

Illustrating Miss Berridge's paper on Spencerites.

Phot. I. Radial section of strobilus. s., stele; $i . c$., inner cortex; $0 . c$, outer cortex; sp., best preserved sporophyll. $\times 7$.

Phot. 2. Tangential section through cortex showing the verticillate arrangement of the leaftraces, l.t. $\times 7$.

Phot. 3. Sporophyll-head seen in radial section (sp. Phot. I), showing the sporangial attachment and the vascular bundle passing out to the distal limb, which has perished. $\times 27$.

Phot. 4. Sporophyll-head with distal limb attached, seen in slightly tangential section. The dorsal lobe is much decayed. $\times 3^{2}$.

Phot. 5. Transverse section of inner, part of axis. $m_{\text {. }}$, pith with central strand of thick-walled cells; $x$., xylem; i.c., inner cortex; l.t., leaf-trace. $\times 35$.

Phot. 6. Transverse section of sporophyll, with distal limb $(a)$ attached. $\times 32$.

Phot. 7. Tangential section of strobilus. sp.ped., cross-section of pedicel of sporophyll. $\times 20$.

Phot. 8. Section through the ventral lobe and sporangial attachment, sp.at. $\times 4^{\circ}$.

Phot. 9. Portion of radial section of the axis, showing the arched leaf-trace, l.t., passing through the outer cortex, o.c., into the base of the sporophyll-pedicel, $p d . ; x$., xylem; $i . c$, inner cortex. $\times 40$.

Phot. 10. Portion of transverse section of axis, showing two leaf-traces. Each leaf-trace appears twice in the section owing to its arched course. 

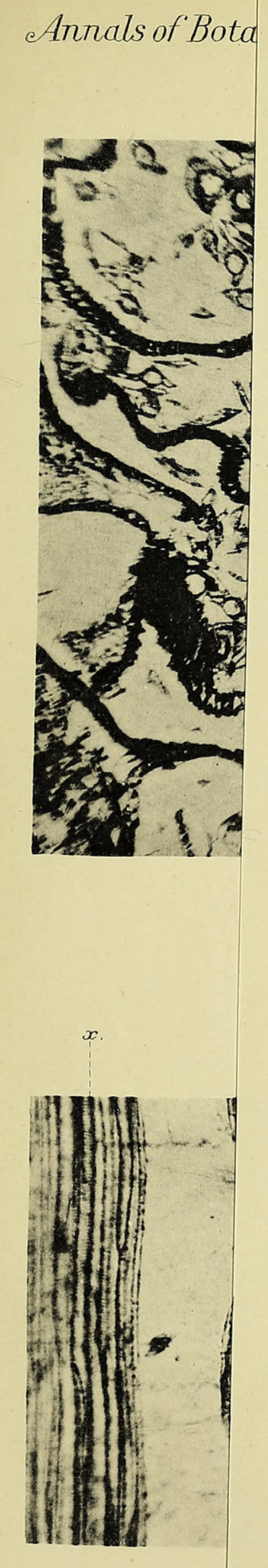

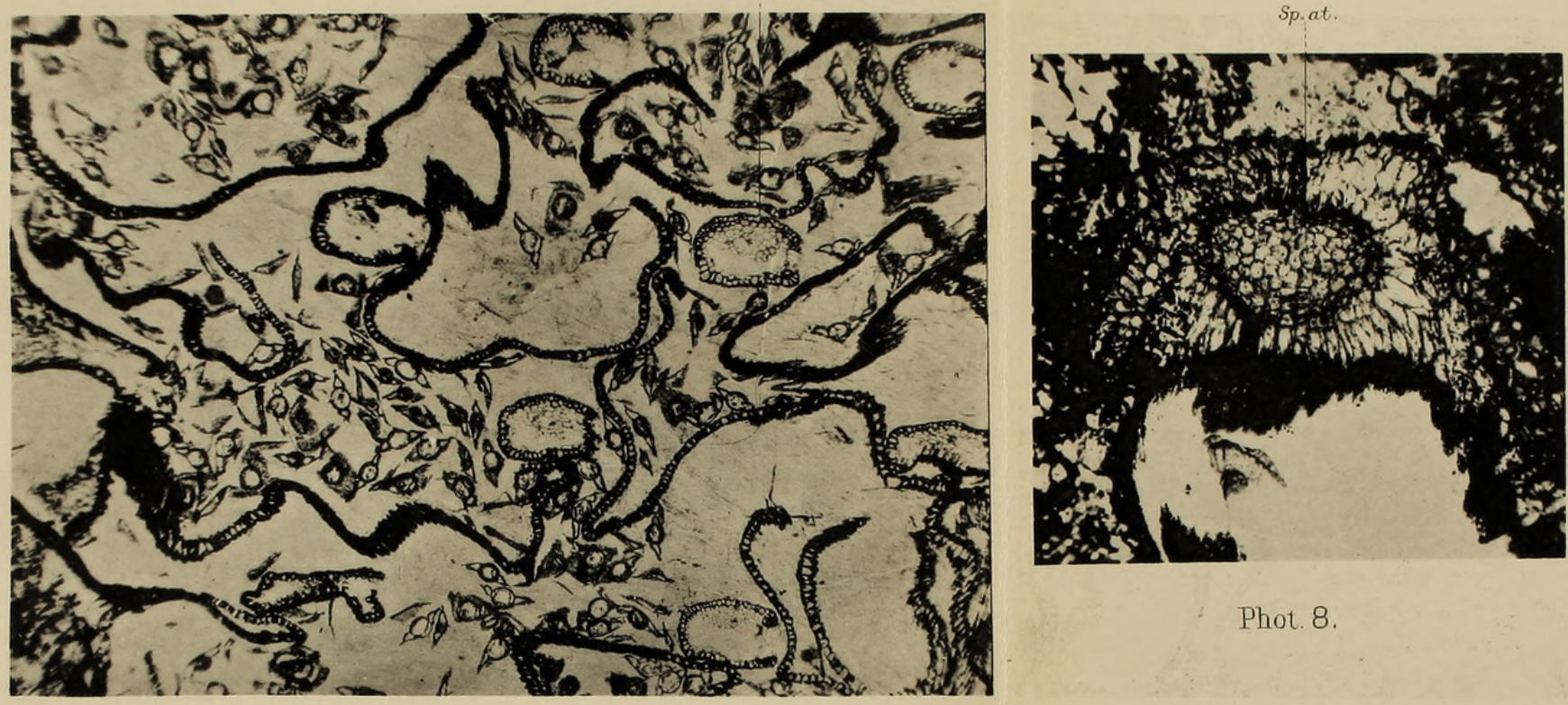

Phot. 8.

Phot 7.

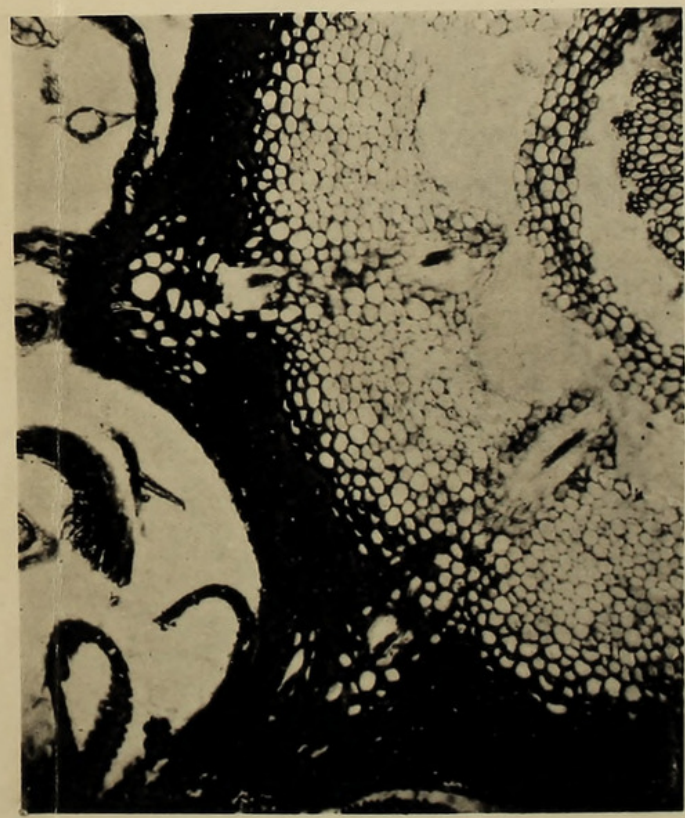




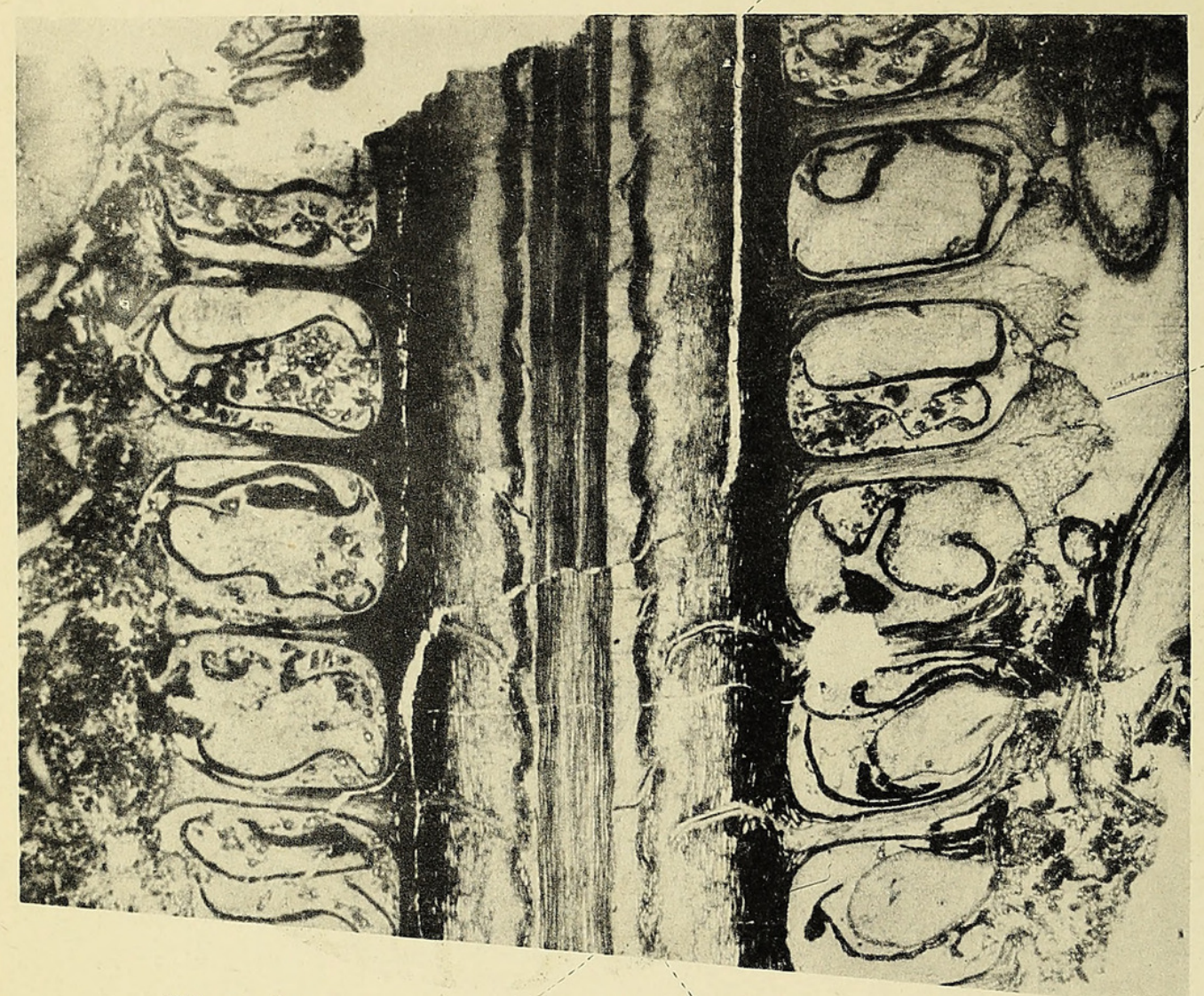

oc.

Phot. 1.

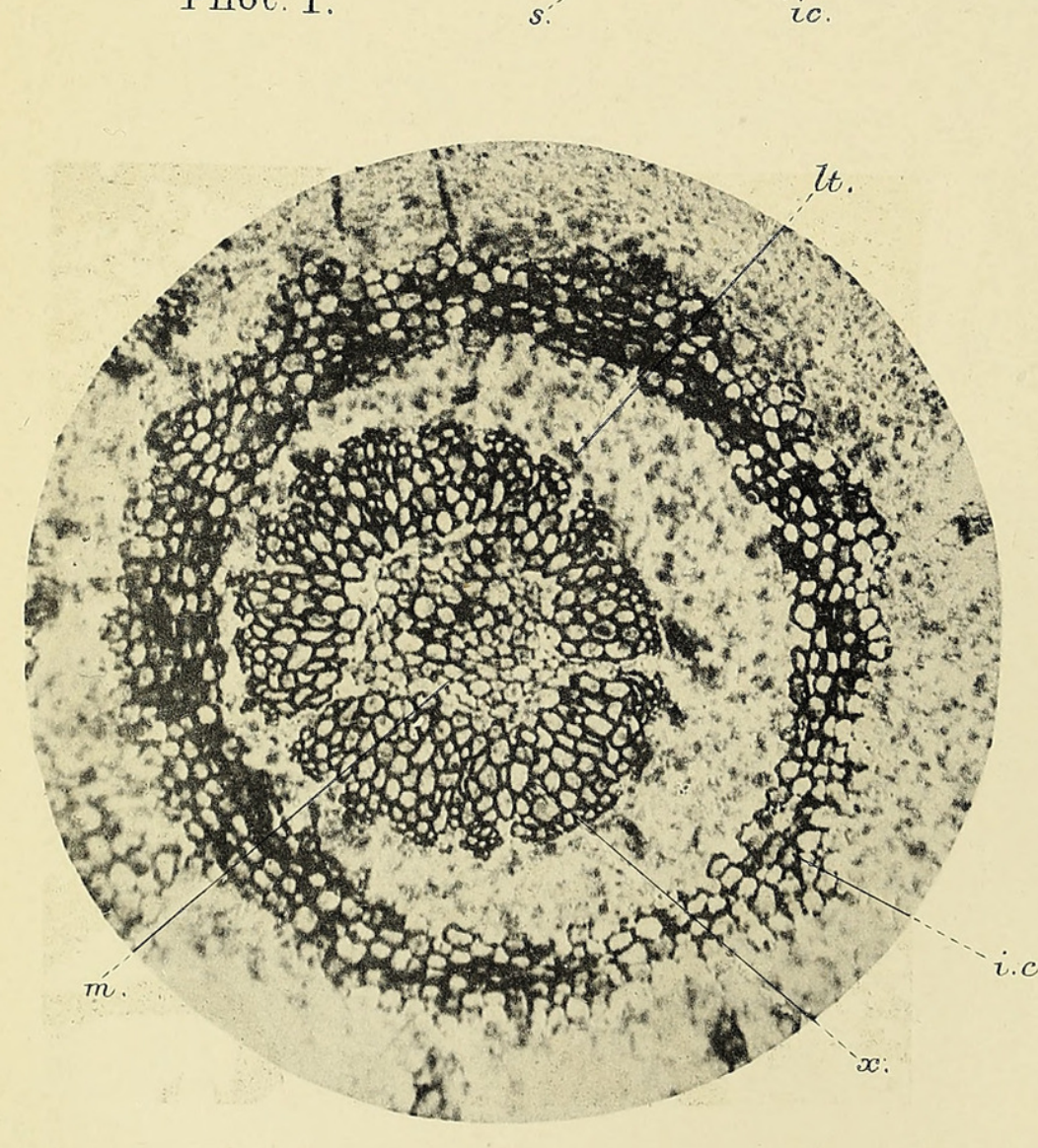

$$
\text { (1) }
$$

$-S_{p}$

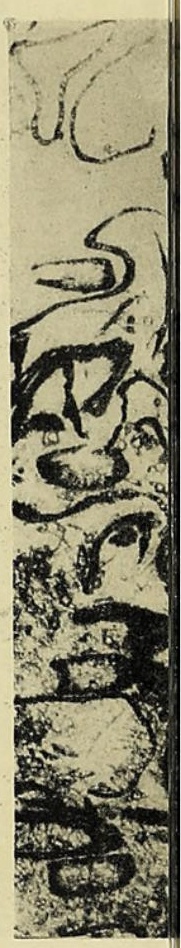

Phot. 5.

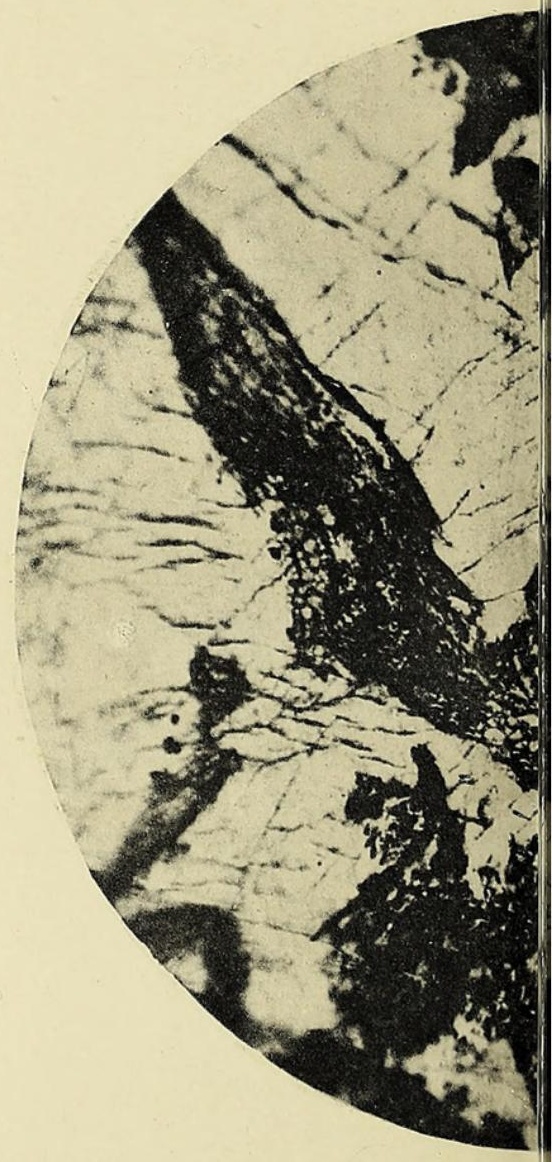




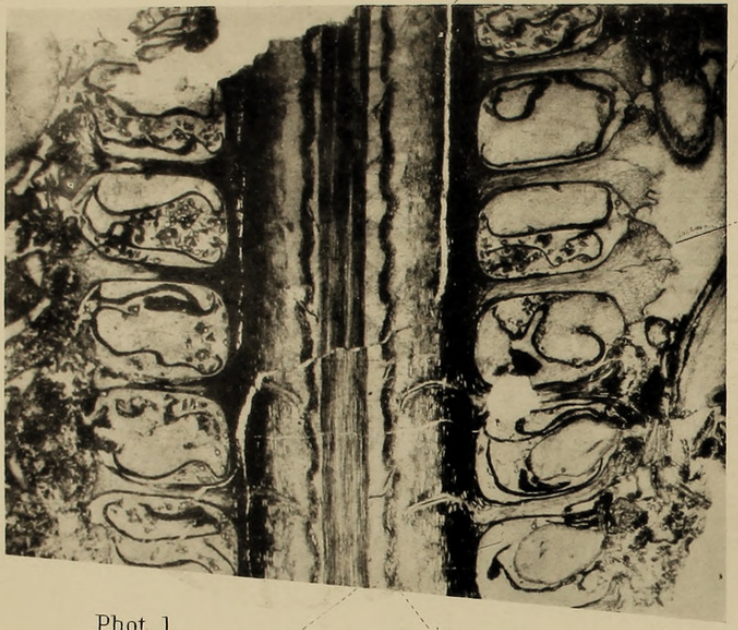

Phot. 1.

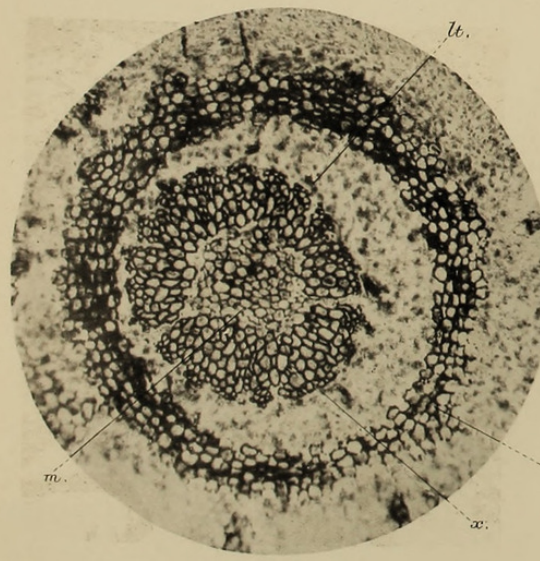

Phot. 5.

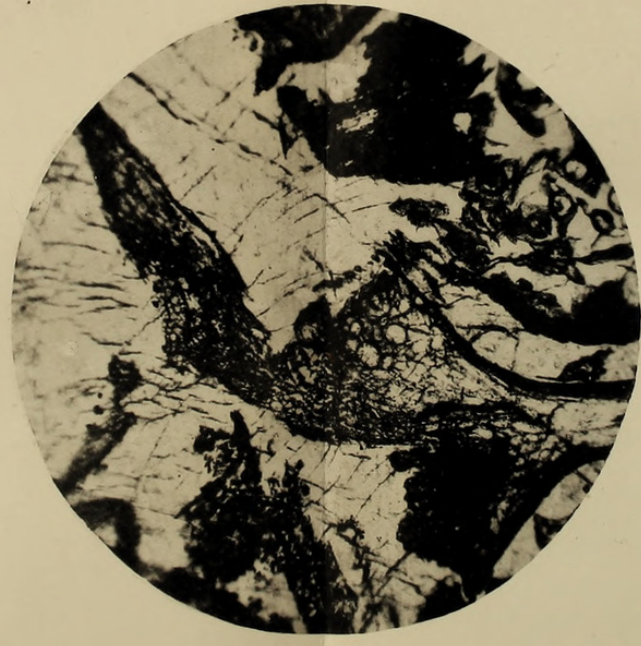

Phot. 4

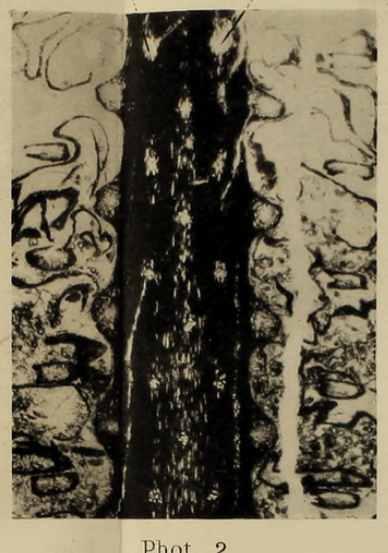

Phot. 2

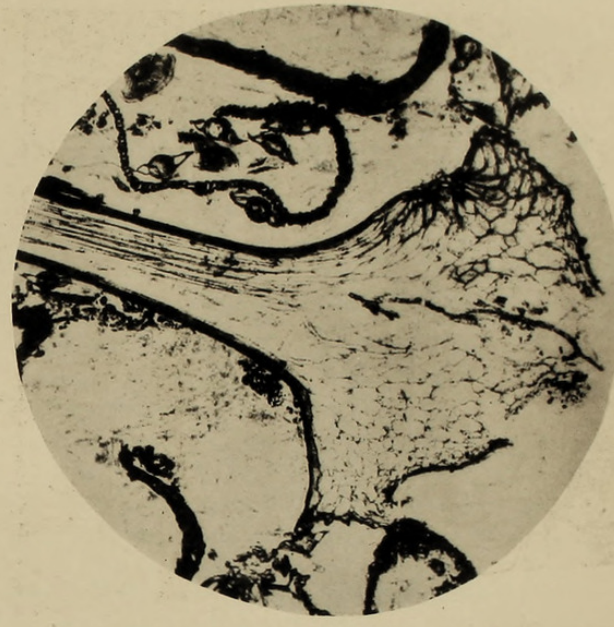

Phot. 3 .

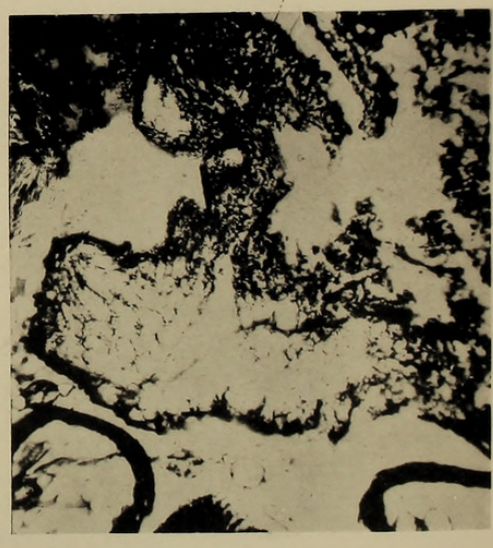

Phot 6 


\section{$2 \mathrm{BHL}$ Biodiversity Heritage Library}

Berridge, Emily Mary. 1905. "On two new specimens of Spencerites insignis." Annals of botany 19, 273-279.

https://doi.org/10.1093/oxfordjournals.aob.a088999.

View This Item Online: https://www.biodiversitylibrary.org/item/233541

DOI: https://doi.org/10.1093/oxfordjournals.aob.a088999

Permalink: https://www.biodiversitylibrary.org/partpdf/318797

\section{Holding Institution}

Smithsonian Libraries

\section{Sponsored by}

Biodiversity Heritage Library

\section{Copyright \& Reuse}

Copyright Status: Not in copyright. The BHL knows of no copyright restrictions on this item.

This document was created from content at the Biodiversity Heritage Library, the world's largest open access digital library for biodiversity literature and archives. Visit BHL at https://www.biodiversitylibrary.org. 